\title{
A PROSPECTIVE STUDY OF LAPAROSCOPIC CHOLECYSTECTOMY VERSUS OPEN CHOLECYSTECTOMY IN PATIENTS WITH CHOLECYSTITIS
}

\author{
Girish Pandey ${ }^{1}$, Suresh S. Karlatif 2
}

${ }^{1}$ Assistant Professor, Department of Surgery, Heritage Institute of Medical Sciences, Varanasi, Uttar Pradesh, India.

${ }^{2}$ Associate Professor, Department of Surgery, Heritage Institute of Medical Sciences, Varanasi, Uttar Pradesh, India.

ABSTRACT
BACKGROUND
Cholelithiasis is one of the major causes of morbidity, particularly in females. Most of the cases of cholelithiasis are silent.
Cholecystectomy is the choice of treatment in symptomatic cholelithiasis. With the introduction of laparoscopic cholecystectomy, it
becomes prudent to verify the advantages over open cholecystectomy.

\section{METHODS}

A prospective study of 160 cases was carried out in the department of surgery in Heritage Institute of Medical Sciences, Varanasi, between January 2017 and June 2018 with the aim to compare open and laparoscopic cholecystectomy. The patients were randomly assigned into two groups. Group A consists of patients who underwent open cholecystectomy and Group B patients underwent laparoscopic cholecystectomy for cholelithiasis.

\section{RESULTS}

Mean duration of surgery was $72.4 \mathrm{~min}$ in open cholecystectomy and $44.7 \mathrm{~min}$ in laparoscopic cholecystectomy which is longer. Duration of post-operative pain relief was 18.3 hours in open cholecystectomy as compared to 1.8 days in laparoscopic cholecystectomy.

\section{CONCLUSIONS}

Laparoscopic cholecystectomy can be recommended as the first choice of operative procedure for patients with cholelithiasis as it involves shorter hospital stay, lesser postoperative pain and better cosmetic results.

HOW TO CITE THIS ARTICLE: Pandey G, Karlatif SS. A prospective study of laparoscopic cholecystectomy versus open cholecystectomy in patients with cholecystitis. J. Evolution Med. Dent. Sci. 2019;8(18):1491-1493, DOI: $10.14260 /$ jemds/2019/331

\section{BACKGROUND}

Gall stones are one of the major causes of morbidity with a prevalence rate of $10-20 \%{ }^{1}$ Open Cholecystectomy is the mainstay of treatment of gall stone diseases. Even though other modalities of treatment exist like oral dissolution of gallstones, ESWL and Lithotripsy, they did not provide desired results in the treatment of gallstones, ${ }^{2,3}$ and hence open cholecystectomy remains the mainstay of treatment. In 1882 German surgeon Karl August Langenbuch performed first open cholecystectomy. ${ }^{4}$ Now with the advent of laparoscopic Cholecystectomy, become the main stay in the treatment of cholelthiasis. First Laparoscopic Cholecystectomy was performed by Philleppe Mouretin Lyon, France.5,6,7 Day by day, more number of surgeons are performing Laparoscopic Cholecystectomy as it provides decreased post-operative hospital stay, decreased postoperative pain and early resumption of normal activities. $^{8}$

Even though Laparoscopic Cholecystectomy offers significant benefits, at the same time it has got its drawbacks like bile duct injuries, longer duration of operating time etc. ${ }^{9}$

'Financial or Other Competing Interest': None.

Submission 15-03-2019, Peer Review 20-04-2019,

Acceptance 26-04-2019, Published 06-05-2019.

Corresponding Author:

Dr. Girish Pandey,

Assistant Professor

Department of Surgery,

Heritage Institute of Medical Sciences,

Varnasi, Uttar Pradesh, India.

E-mail: girishpandey1616@gmail.com

DOI: $10.14260 /$ jemds $/ 2019 / 331$
Open Cholecystectomy is preferred to Laparoscopic Cholecystectomy in cardiac patients, in such cases Carbon dioxide insufflations can lead to cardiac arrhythmias. ${ }^{10}$ The setup of Laparoscopic unit initially needs cost, and skill to acquire some time for Laparoscopic surgeries as compared to open Cholecystectomy. Taking all these factors it needs further studies to highlight the superiority of Laparoscopic Cholecystectomy versus open cholecystectomy.

\section{METHODS}

A prospective study of 160 patients was conducted in the Department of surgery in Heritage Institute of Medical Sciences, Varanasi between January 2017 and June 2018. All the patients having gall stones with symptoms were admitted and detailed history was taken and after proper examination was done including investigations like complete blood count, Liver Function Tests, X-ray, USG abdomen, RBS and Sr. Creatine and it was decided to subject patients for cholecystectomy.

Patients were grouped into two groups. Group A consists of patients who underwent open cholecystectomy and group B patients underwent Laparoscopic Cholecystectomy. The patients were explained about the procedure in both the groups. The patients were evaluated for duration of surgery, duration of the postoperative pain, period of post-operative hospital stay, post-operative resumption of normal activities.

\section{Statistical Analysis}

The data was collected and analysed using standard statistical chi - square test, $\mathrm{p}<0.05$ statistically significant. Data was entered in Microsoft excel and analysis was done using SPSS version 22. 


\section{RESULTS}

Majority of patients were females (78.125\%). There were 76 females and 24 males in Laparoscopic Cholecystectomy (LC) group and 49 females and 11 males in open Cholecystectomy (OC) group.

\begin{tabular}{|c|c|c|c|c|}
\hline Sex & Group A (OC) & $\mathbf{\%}$ & Group B (LC) & $\mathbf{\%}$ \\
\hline Male & 11 & $18.33 \%$ & 24 & $24 \%$ \\
\hline Female & 49 & $81.66 \%$ & 76 & $76 \%$ \\
\hline Total & $\mathbf{6 0}$ & $\mathbf{1 0 0}$ & $\mathbf{1 0 0}$ & $\mathbf{1 0 0}$ \\
\hline \multicolumn{5}{|c|}{ Table 1. Sex Distribution } \\
\hline
\end{tabular}

Age of patients varies from 18 years to 72 years and majority of belonging to the age group of 41-60.

\begin{tabular}{|c|c|c|c|c|}
\hline Age Group & Group A (OC) & $\mathbf{\%}$ & Group B (LC) & $\mathbf{\%}$ \\
\hline $\begin{array}{c}\text { Less than } 20 \\
\text { Yrs. }\end{array}$ & 1 & $1.66 \%$ & 2 & $2 \%$ \\
\hline $21-40$ Yrs. & 16 & $26.66 \%$ & 34 & $34 \%$ \\
\hline $41-60$ Yrs. & 40 & $66.66 \%$ & 60 & $60 \%$ \\
\hline $61-80$ Yrs. & 3 & $5 \%$ & 4 & $4 \%$ \\
\hline Total & $\mathbf{6 0}$ & $\mathbf{1 0 0}$ & $\mathbf{1 0 0}$ & $\mathbf{1 0 0}$ \\
\hline \multicolumn{5}{|c|}{ Table 2. Age Distribution } \\
\hline
\end{tabular}

Patients presented with pain in the right hypochondrium, dyspepsia, jaundice, nausea, vomiting and postprandial fullness, sometimes fever. Most common presentation was pain in the right hypochondrium.

\begin{tabular}{|l|c|c|c|c|c|c|}
\hline & Pain & $\begin{array}{c}\text { Postprandial } \\
\text { Fullness }\end{array}$ & $\begin{array}{c}\text { Nausea, } \\
\text { Vomiting }\end{array}$ & Dyspepsia & Fever & Jaundice \\
\hline LC & 45 & 30 & 27 & 17 & 11 & 8 \\
\hline OC & 48 & 34 & 27 & 16 & 14 & 6 \\
\hline
\end{tabular}

Table 3. Symptom Profile of Patients in Both Groups

The time taken for Laparoscopic Cholecystectomy 40-60 min (mean $44.7 \mathrm{~min}$ ) was lower as compared to open Cholecystectomy 50-95 min (mean $72.5 \mathrm{~min}$ )

\begin{tabular}{|c|c|c|}
\hline Operative Time & Group A (OC) & Group B (LC) \\
\hline Less than $40 \mathrm{~min}$ & 4 & - \\
\hline $41-50 \mathrm{~min}$ & 78 & 1 \\
\hline $51-60 \mathrm{~min}$ & 18 & 15 \\
\hline $61-70 \mathrm{~min}$ & - & 40 \\
\hline $71-90 \mathrm{~min}$ & - & 4 \\
\hline \multicolumn{2}{|c|}{ Table 4. Duration of Surgery } \\
\hline
\end{tabular}

The patients who underwent Laparoscopic Cholecystectomy experienced less postoperative pain as compared to open Cholecystectomy and earlier relief. In patients who underwent Laparoscopic Cholecystectomy mean duration of postoperative pain was $18.4 \mathrm{hrs}$ as compared to mean duration of $31.6 \mathrm{hrs}$. In open Cholecystectomy cases. Post-operative hospital stay was shorter in Group B than in Group A. The mean period of hospital stay was 5.2 days in Group A and 2.1 days in Group B.

\begin{tabular}{|c|c|c|c|c|c|}
\hline & $\begin{array}{c}\text { Less Than } \\
\text { 2 Days }\end{array}$ & $\begin{array}{c}\mathbf{2 - 3} \\
\text { Days }\end{array}$ & $\begin{array}{c}\mathbf{3 - 4} \\
\text { Days }\end{array}$ & $\begin{array}{c}\mathbf{4 - 5} \\
\text { Days }\end{array}$ & $\begin{array}{c}\text { More Than 5 } \\
\text { Days }\end{array}$ \\
\hline OC & --- & --- & 10 & 35 & 15 \\
\hline LC & 70 & 20 & 10 & --- & --- \\
\hline \multicolumn{6}{|c|}{ Table 5. Duration of Hospital Stay after Surgery } \\
\hline
\end{tabular}

Apart from surgical site infection no other forms of complications were not seen in the present study groups.

\section{DISCUSSION}

Carl Langenbuch who first did open Cholecystectomy way back in 1882 at Germany, very famously stated that "gall bladder should be removed just not because it contains stones, but it forms them."11

In both types of surgeries, the aim is to provide relief of pain by safely removal of gall bladder. Even though the indications for both surgeries is same, the choice of the procedure depends upon patient's preference, cost of procedure, duration of postoperative hospital stay and surgeon's expertise. More number of patients prefers Laparoscopic Cholecystectomy as it provides better cosmetic results, reduced hospital stay and patients' satisfaction. ${ }^{12,13}$

In the present study females outnumbered (79\%) and majority were in the age group of 41-60 years. These findings are in consistent with results of similar studies.14,15 Time taken for Laparoscopic Cholecystectomy (44.7) was less than for the open Cholecystectomy (72.4) in the present study. Similar findings were noted by Pessaux P et al. In their study duration of surgery was shorter in Laparoscopic Cholecystectomy than in Open Cholecystectomy (103.3 min versus $149.7 \mathrm{~min}$ ). ${ }^{10}$ Waldner $\mathrm{H}$ et al, found there was no significant difference between both surgeries. ${ }^{16}$ However most studies reported Open Cholecystectomy to take lesser time than Laparoscopic Cholecystectomy.17, 18,19 The above is explained as it takes longer time to acquire Laparoscopic Cholecystectomy skills and hence depends on the experience of the operating surgeons.

Relief of postoperative pain duration was as follows 18.3 hours in LC and 30.8 hours in Open Cholecystectomy, which is similar to study conducted Shukla A et al 14.8 and 27.92 hours respectively. ${ }^{15}$ It was also observed that patients undergoing open Cholecystectomy required more doses of analgesics as compared to Laparoscopic Cholecystectomy. ${ }^{19}$

The mean period of postoperative hospital stay was 1.92 days in Laparoscopic Cholecystectomy group and 5.2 days in open Cholecystectomy group which was similar to Anmol $\mathrm{N}$ et al study wherein 3 days in Laparoscopic Cholecystectomy group and 7 days in open Cholecystectomy group. ${ }^{20}$ In another study by Karim $\mathrm{T}$ et al 3.7 \& 5.46 were noticed for Laparoscopic Cholecystectomy and open Cholecystectomy groups respectively. ${ }^{21}$

\section{CONCLUSIONS}

Gall stone disease is a major problem in India. The main modality of treatment remains cholecystectomy. Laparoscopic cholecystectomy can be recommended as the first choice of operative procedure for patients with cholelithiasis as it involves shorter hospital stay, lesser postoperative pain, better cosmetic results and fewer incidences of surgical site infection.

\section{REFERENCES}

[1] Doke A, Gadekar N, Gadekar J, et al. A comparative study between open versus laparoscopic cholecystectomy. Sch J App Med Sci 2016;4(1):57-61. 
[2] Villanova N, Bazzoli F, Taroni F, et al. Gallstone recurrence after successful oral bile acid treatment. A 12 year follow up study and evaluation of long term post dissolution treatment. Gastroenterol 1989;97(3):726-31.

[3] Bianca DP, Bonvin B. Lithotripsy of biliary calculi by shock waves. Current possibilities and perspectives. Helv Chir Acta 1990;56(6):913-6.

[4] Gadacz TR, Talamini MA. Traditional versus laparoscopic cholecystectomy. Am J Surg 1991;161(3):336-8.

[5] McSherry CK. Open cholecystectomy. Am J Surg 1993;165(4):435-9.

[6] Ji W, Li LT, Li JS. Role of laparoscopic subtotal cholecystectomy in the treatment of complicated cholecystitis. Hepatobil Pancreat Dis Int 2006;5(4):584-9.

[7] Cuschieri A, Laparoscopic cholecystectomy. J R Coll Surg Edinb 1999;44(3):187-92.

[8] Starsberg SM. Clinical practice. Acute calculous cholecystitis. New England Journal Med 2008;358(26):2804-11.

[9] Paulino-Netto A. A review of 391 selected open cholecystectomies for comparison with laparoscopic cholecystectomy. Am J Surg 1993;166(1):71-3.

[10] Pessuaux P, Regenet N, Tuech JJ, et al. Laparoscopic cholecystectomy versus open cholecystectomy: a prospective comparative study in the elderly with acute cholecystitis. Surg Laparosc Endosc Percutaneous Tech 2001;11(4):252-5.

[11] Oslen DO. Mini versus Lap. Cholecystectomy. Am J Surg 1993;165:440-3.

[12] Goco IR, Chambers LG. Dollar and cents: minicholecystectomy and early discharge. South Med J 1988;81(2):161-3.
[13] O’Dwyer PJ, McGregor JR, McDermott EW, et al. Patient recovery following cholecystectomy through a $6 \mathrm{~cm}$ or $15 \mathrm{~cm}$ transverse subcostal incision: a prospective randomized clinical trial. Postgraduate Medical Journal 1992;68(804):817-9.

[14] Otibi RF, Junied NJA. A comparison of open cholecystectomy surgical method with the laparoscopic one. International J Healthcare Sci 2016;3(2):217-22.

[15] Shukla A, Seth S, Ranjan A. A comparative study between laparoscopic and open cholecystectomy in cases of cholecystitis with cholelithiasis: one year experience in tertiary care center. Int Surg J 2017;4(3):903-7.

[16] Waldner H. Laparoscopic cholecystectomy versus open cholecystectomy in acute cholecystitis. Langen Becker Arch. Chirsuppl Kongress BD 1997;144:11779.

[17] Agrawal SN. A study of open versus. Laparoscopic management of cholecystectomy. International Medical Journal 2016;3(2):219-21.

[18] Marthandam S, Reddy AC. Lparoscopic versus minilaparotomy cholecystectomy. A comparative study. IOSR Journal of Dental and Medical Sciences 2015;14(7):25-34

[19] Kumar L, Manish, Singh AP. A comparative study of laparoscopic vs. open cholecystectomy in a northwestern Medical school of Bihar. JMSCR 2017;5(5):22647-52.

[20] Anamol N, Lakshminarayan G, Manohar TM, et al. Outcome following open and laparoscopic cholecystectomy. J Evolution Med Dental Sci 2014;3(15):4061-71.

[21] Karim T, Kadyal A. A comparative study of laparoscopic versus open cholecystectomy in suburban teaching hospital. J Gastrointest Dig Syst 2015;5:371. 